(C) EUSP, 2017 (e) $\quad$ ISSN 2310-3817 Vol.5 SUCSIS No.2(engl) p. 192-203

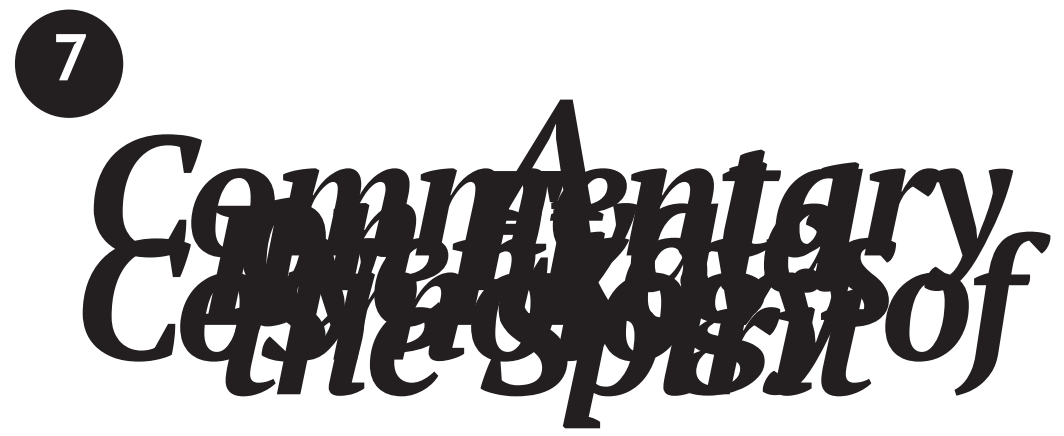

\title{
Giuliano Vivaldi
}

\section{A Commentary on Evald Ilyenkov's Cosmology of the Spirit}

\begin{abstract}
This article traces the publication history of Evald Ilyenkov's early text, "Cosmology of the Spirit," it presents its key historical and intellectual contexts and influences, and provides an overview of the contemporary literature related to its interpretation. The commentary also explains the translator's choices in his work with Ilyenkov's terminology.

\section{Keywords}

Ilyenkov, philosophy in the USSR, cosmology, Hegel, Spinoza, Engels, Pobisk Kuznetsov
\end{abstract}




\section{A Commentary on Evald Ilyenkov's Cosmology of the Spirit}

The slow but gradual recognition of Soviet philosophy as worthy of attention in the Anglo-Saxon world in recent years arguably arose with the publication of David Bakhurst's study Consciousness and Revolution in Soviet Philosophy: from the Bolsheviks to Evald Ilyenkov (1991), a volume that posits Ilyenkov at the center of any contribution Soviet philosophy may have in world philosophy and rescuing the reputation of Soviet philosophy, one hitherto seen as "dismal" (Bakhurst 2013). Although Ilyenkov has been translated into a number of languages (most notably into Italian at a very early stage), he hasn't always fared as well in English as he had in other languages. The occasional translations of his works that were available in the Soviet period did not always do justice to the breadth of Ilyenkov's thought (suffering as they did too from "editorial interference" as Bakhurst put it [1999: 9]). Fortunately, in more recent years one of Ilyenkov's seminal texts "Dialectics of the ideal" has been felicitously translated following the publication of the unredacted and unabridged essay in the original Russian (Levant and Oittinen 2014). Translating "Cosmology of the Spirit" aims to present a very original and early piece of Ilyenkov's work that the present commentary aims to set in its context, providing a history and geneaology of this text along with a discussion of its location within Ilyenkov's oeuvre and in the traditions of Russian and Soviet philosophy. I will try to pinpoint the various sources that influence the text, while also discussing the peculiarities of the text itself which pose a number of translation issues. Evald Ilyenkov's "Cosmology of the Spirit" is arguably one of the most curious texts of that all too rarely explored (and all too often submerged from view), "Red Atlantis" of creative Soviet Marxism. ${ }^{1}$ One could equally justify using the term "subterranean Marxism" to place Ilyenkov as part of a strand of Marxism that arose in the Soviet Union and which the Soviet establishment all too often saw as inimical and would try to do its best to hinder its progress. Belonging to a liminal discursive space, Ilyenkov's text has rarely been given the attention it merits. In his book E. V. Ilyenkov: Zhit' filosofiey [E. V. Ilyenkov: A philosophical life], Sergei Mareev recounts how Ilyenkov's doctoral dissertation supervisor, T. Oizerman (and one of the figures in the Soviet academic sphere most acquainted with Marxist theory and most knowledgeable about the works of Marx) opposed the inclusion of this text in a proposed (but then postponed) two-volume publication of the selected works of Ilyenkov after the philosopher's death by suicide in the late 1970s (Mareev 2015: 156). Publication would have to wait until 1988 in the journal Nauka i Religiia, and the full text would have to wait another three years before it was published in a single volume of selected texts by

A term first used by James Hoberman in his book The Red Atlantis: Communist Culture in the Absence of Communism (1998) and the term "creative Soviet Marxism," I have borrowed from Alex Levant and Vesa Oittinen who used this term to subtitle an introductory volume on Ilyenkov's “Dialectics of the Ideal” (Levand and Oittinen 2014). 


\section{Giuliano Vivaldi}

Ilyenkov entitled Filosofiia i Kultura [Philosophy and culture] (1991: 41537). ${ }^{2}$ Ever since its publication, "Cosmology" has remained a singularly neglected text in Ilyenkov's oeuvre. In literature on Ilyenkov, references to it are rare and commentaries hard to come by. Apart from Sergei Mareev's chapter-long sustained commentary (2015: 156-70), the text is seldom mentioned in terms of its philosophical context or content.

Indeed, any commentaries that do exist on this text have often been made from a variety of different quarters: cosmonauts (Sevastyanov 1988), physicists and mathematicians (Barashenkov 1988), and literary novelists and publicists (Tsvetkov 2013) have commented on this text from their particular perspectives, as have philosophers. Other Ilyenkov specialists such as Vesa Oittinen and Andrei Maidansky have made some illuminating comments on the text, albeit fairly brief ones. These diverse readings from different quarters testify to the versatility and multivalent nature of the text. ${ }^{3}$ Something that, in turn, relates to the strange concatenation of influences permeating through the text as it does to the multiple sources of its thinking and its interesting origin.

\section{Origin of the Text}

Again it is Sergei Mareev, Ilyenkov's most consistent exegete and proselytiser, who relates the origin of the text to the curious figure of Pobisk Georgievich Kuznetsov (Pobisk being one of those popular, revolution-inspired names, comprising the first letters of: "Generation of the Octobrist Fighters and Builders of Communism”!). According to Mareev, after being severely injured during the Second World War, Pobisk began to devote himself to the question of the origin of life (Mareev 2015: 157). Not content with the traditional Engelsian response that life is the mode of existence of protein bodies that had become the standard Soviet answer to this subject matter, Pobisk started to pose the question not of how life emerged, but for what reason life emerged. A question provoked by his reading of the cosmological philosophers of the nineteenth century such as Vladimir Vernadsky, cosmic biologist Alexander Chizhevsky, as well as the central figure of Russian cosmist philosophy, Nikolai Fedorov and his

2 This translation also consults with the original manuscript found recently in Ilyenkov's archive

Ilyenkov was even to feature in a curious tract entitled Prestupnye filosofy [Criminal philosophers] by a certain Nikolai Vladimirovich Nosov (not to be confused with the Soviet children's writer Nikolai Nikolaievich Nosov), lumping him together with other (to his mind) "criminal elements" such as Socrates, Cicero, and Machiavelli. Ilyenkov's crime, in Nosov's eyes, was that of attempting to inculcate in humankind the murderous-suicidal aim of Marxist reason-that of destroying the universe (Nosov 2007: 166-84)! It seems that Nosov discovered Ilyenkov's criminal intent exclusively through his reading of the Cosmology text. 
vision of the revivification of decaying worlds. For his attempts to form discussion groups about these subjects, Pobisk Kuznetsov ended up in jail more than once (on one occasion arrested from his hospital bed). Ilyenkov, however, was later to encourage Kuznetsov to publish his thoughts. According to Mareev, the central concept that Ilyenkov took from Kuznetsov's work, along with others' writings, was the fundamental notion of infinity as a circle (or big circle) rather than some straight monotonous line veering off into some foggy distance (Mareev 2015: 15761). A big circle whose "beginning" and "end" were linked, or interlocked, by mind or reason. Therefore, thought is given a certain cosmic purpose or role, one that is central and essential to universal interaction and subject to the question not only of why or how but also "what for." The role Ilyenkov assigns to reason, albeit a tragic one, is an eminently noble one of repaying its debt to nature through self-sacrifice and so playing a fundamental role in re-activating this big circle.

\section{Influences}

Engels's oft-maligned "Dialectics of Nature" clearly provides the citational husk for Ilyenkov's "Cosmology," although it is not necessarily the source of central concepts in Ilyenkov's text. ${ }^{4}$ However, perhaps the three most significant influences to be found in the text are those of Spinoza, Russian cosmism and, of course, Hegel, whose terminological presence is fundamental. Ilyenkov, according to Andrei Maidansky, exhibits a "western mind on Russian soil" (2014b: 537), but in this early text Ilyenkov tends to place the more essentially Russian cosmist thinkers alongside Spinoza. At the same time, as Maidansky demonstrates, Ilyenkov demolishes the archaic collectivism of Orthodox religiosity and communitarianism and can be characterized as "rowing against the stream" (Maidansky 2014b: 538) of Russian religious philosophy, exemplifying Spinozalike logic over emotion.

Spinoza is mentioned four times in the "Cosmology" in conjunction with a variety of different philosophers (from Bruno through to Engels, Hegel, Fichte, and Lenin). Each mention of Spinoza's name is directly linked to Ilyenkov's formulation of his own dialectical materialism (as op-

\footnotetext{
However, the influence of Engels's work on the thinking behind the "Nagoya Model" and the "Sakata Model," inspiring Quark Theory, has been well-documented and testified by Shoichi Sakata himself who wrote: "Although the contents of the dialectics of nature [...] are supplemented by the remarkable progress of individual sciences, they are not essentially different from those stated by Engels at the end of the last century. The contents of the dialectics of nature must be enriched constantly in the future by the development of science, but the essential features such as discussed previously, will never be lost through all ages. Because, it is "the logic of nature" (Sakata 1971 [1947]).
} 


\section{Giuliano Vivaldi}

posed to the Soviet form of diamat, or old school mechanical materialism, with which it was linked) and will later forge his fierce antipositivistic stance. Spinoza here is key in restoring a fundamentally materialist principle that had been entirely lost to thought in mechanical materialism and Soviet diamat:

Dialectical materialism restores the simple and profound statement of Bruno and Spinoza in a rational form, that in matter, taken as a whole, development lies in their actual consummation at every finite moment of time; in matter, all the stages and forms of the necessary development are, simultaneously, found in their actual realisation (Ilyenkov 1991: 415). ${ }^{5}$

Moreover, the talk of "a dialectic and materialist, the kind of materialist like Spinoza" leads us to the central pivotal thesis of the text: "Just as there is not thought without matter, understood as substance, so there is not matter without thought, understood as its attribute" (Ilyenkov 1991: 416).

In his work Dialectical Logic, Ilyenkov devotes an entire chapter to Spinoza entitled "Thought as an Attribute of Substance." (Ilyenkov 2008: 27-74) This chapter restates the Spinozan monism at the heart of Ilyenkov's thinking from "Cosmology" onwards, and illuminates the role of the thinking body (or the thinking brain-the term most often used in "Cosmology" but which Mareev [2015: 162] sees as an unfortunate vestige of diamat) and confirms Ilyenkov's Spinozan proposition of the role of Thought as attribute of Matter. In this later work, he returns to his earlier position in "Cosmology" where he writes of "Matter constantly possessed of and thinking of itself," and whereby the thinking brain (Man) becomes "one of the necessary links, locking together the universal big circle of universal matter" (Ilyenkov 1991: 419). For as Ilyenkov later states in Dialectical Logic:

It is in man that Nature really performs, in a self-evident way, that very activity that we are accustomed to call 'thinking. In man, in the form of man, in his person, Nature itself thinks, and not at all some special substance, source, or principle instilled into it from outside. In man, therefore, Nature thinks of itself, becomes aware of itself, senses itself, acts on itself (Ilyenkov 2008: 33-34, emphasis in original).

Man's (thinking being's) ultimate role, or "mission” as Maidansky puts it (2014a: 128), is to resist entropy and finally embody a tragic selfsacrifice that will return a freezing "cold of intergalactic space [...] to the fiery incandescent 'youth’ of cosmic matter” (Ilyenkov 1991: 424-25),

Unless otherwise stated translations are my own. 
thus starting a new cosmic circle. It is this perishing of man that produces a tragically pessimistic note in Ilyenkov's text, while the contemplation of the thinking being's mission nonetheless serves at the same time for the formation, or foundation, of a new kind of universal pathos.

In the radiance of the starry sky, the thinking being will see a testimony to the power and beauty of the immortal even in the death of its thinking spirit-objectified, sensually perceptible, but not calling into any doubt its own power over the sensible world [...] Conscious of the colossal scale of its role in the universe, the human being discovers also the high sensation of their highest purpose; the highest goals of its existence in the world. Its activity is filled with new pathos, before which the pathetic pathos of religion will fade. This will be a pathos of truth, a pathos of the true consciousness of its objective role in the universal system (Ilyenkov 1991: 435-36).

This vision of a pathos of truth and pathos of the true consciousness of its objective role in the universal system, conscious of its own sacrificing role arguably demonstrates a further source of Ilyenkov's cosmology to which both Mareev and Oittinen both make specific reference: Russian cosmism in the guise of Nikolai Fedorov's "Common Task." One similarity, Mareev notes, is where both Ilyenkov and Fedorov see the highest assignment of reason as that of returning its own debt to nature, that is, the universal task, something opposed to the worldviews of positivism and individualism. Their commonality of position lies in their common critique of positivism as the "philosophy of banalities."(Mareev 2015: 168) Fedorov and Ilyenkov instead "attempted to unite Heaven and Earth, Science and Religion, Physics and Poetry in a higher synthesis" with a sublation of religion into this manifestation of a cosmology both "cosmic and substantial" (Mareev 2015: 166-70).

\section{Translation of Terminology}

Often both the first and the final issue for a translator is that of finding the correct translation of a title. Here, too, Ilyenkov presents a problem. There are many reasons as to why "Cosmology of the Spirit" would be the more correct title as dukh is almost exclusively rendered as spirit in conventional translation. Moreover, there is a powerful correlation between geist and $d u k h$ in what is, perhaps, the most significant translations into Russian of Hegel's Phänomenologie des geistes-Gustav Shpet's translation eventually published in $1959 .{ }^{6}$ Nonetheless, while the source of the

6 See George L. Kline's discussion of this translation in Tihanov (2009: 14056). 


\section{Giuliano Vivaldi}

title, the Hegelian term dukh (Geist), is not always unequivocally transformed into spirit in the English translation and even some Hegelian terms such as "world spirit" (Weltgeist) may be rendered occasionally as mirovoj razum rather than mirovoj dukh in Russian too, it was felt that given the more conventional correlation between Phenomenology of the Spirit (Phänomenologie des geistes) and Fenomenologiia dukha, then "Cosmology of the Spirit" would be the better choice of title. The spirit the title refers to, nonetheless, is the thinking being, or thinking mind or brain - the central and most necessary link in the "big circle" of universal matter. So while there is definitely an unresolved tension that needs to be grappled with concerning the title, ${ }^{7}$ it was considered appropriate, therefore, to allude to and follow the more conventional correlation between Hegel's geist, the Russian dukh and the English spirit.

My attempt at translating this early text by Ilyenkov posed a number of issues from the highly conceptual to some rather slighter stylistic conundrums. Attempting to reproduce the style of the text itself was a major consideration. I would term the text a liminal one (it veers from the spheres of philosophy to the natural sciences but also on occasion having the feel of a science fiction text), zigzagging from philosophical considerations and then honing in onto propositions of natural science while then encapsulating an overall vision of reason in more lyrical passages in which Ilyenkov describes a new higher pathos of reason and truth. Ilyenkov manages to create a text whose ensemble he himself describes as a "philosophical and poetical fantasmagoria." In this way, a translation of such a text doesn't simply pose the anticipated issues of a philosophy text but needs to be aware of the different styles in this polyvalent text and to involve a strategy of coping with this.

A minor example of one unexpected source of difficulty was Ilyenkov's use of the dialect word tsutsik, a southern Russian word which has an equivalent in the word nesh (but is much less commonly used, apart from a few regions of England such as Staffordshire, the East Midlands, Lancashire, South Yorkshire and Shropshire, but is rather unknown outside these regions in the English-speaking world), to denote a being extremely susceptible to the cold. However, in the word there is also a possible allusion to the Ukrainism tsu-tsu, denoting a puppy. Choosing the

7 In the volume edited by Vesa Oittinen and Alex Levant, Dialectics of the Ideal: Evald Ilyenkov and Creative Soviet Marxism (2014), this text is translated on page 108 as "Cosmology of the Spirit" (in an essay by Vesa Oittinen), whereas on page 128 in the essay by Andrey Maidansky it is translated as "Cosmology of the Mind." Demonstrating that there is still yet to be any conventional title for the work in English.

$8 \quad$ Aleksei Tsvetkov is surely not altogether wrong to discuss the Strugatsky Brothers in connection with this text in his article on Ilyenkov. After all, the title of their novel A Billion Years Till the End of the World fits very well into the ideas found in this "Cosmology." 


\section{A Commentary on Evald Ilyenkov's Cosmology of the Spirit}

latter over the former is partly related to the very rare use of the word nesh in written English. Translating Ilyenkov taught me that there is a strange lack of terms in the English language for a creature incredibly susceptible to the cold (something not true of other languages such as Italian or Spanish, for example). The image of a frozen and helpless puppy leads us to think of Goya's celebrated painting (although, it can only be pure speculation as to whether Ilyenkov had this in mind).

Yet this slight problem was indicative of something else in the Ilyenkov text. Philosophical rigor was accompanied by an unusual playfulness with certain overtly Romantic sentiments (a paean to Ilyenkov's Wagnerian tastes?). Otherwise there were the conundrums over whether to use the translations of some of the terms used in the Clemens Dutt's translation of Engel's “Dialectics of Nature" (1987) or to remain with more acceptable ones. One of the more intractable ones was that of vysshii tsvet, which suggests something like "most sublime color or blossom," and which is a calque from the Hegelian Höchste blüte (literally "highest blossoming" but in the 1987 English-language translation of Engels it was rendered as "highest creation") Again, conventionally this has been translated as Highest Creation (for example in Engels's "Dialectics of Nature" of which there is a citation including this term in Ilyenkov's "Cosmology"), and so loses all connotations of the German and Russian originals. To complicate matters, Ilyenkov also playfully uses this term in a metaphorical sense. So here too there was yet another conflict between choosing to highlight either the philosophical rigor and philosophical sources or the Ilyenkovian playfulness of the text (both of which are present in the Russian but which in English require some form of sacrifice or other).

One was also tempted to translate Mysliiashchii mozg as "thinking mind" rather than "thinking brain," but then mind, too, was that slippery customer (sometimes overlapping with razum and as one possible alternative to the word spirit to translate $d u k h$ ). Razum was another conundrum. Beyond mind, it could also occasionally be translated as both Reason and, in terms of its inclusion in the Hegelian collocation mirovoi razum, (World) Spirit.

Even here while mirovoi conventionally was translated with the term universal, this translation was, also that which generally rendered vseobshchee. ${ }^{9}$ There was a certain delineation in Ilyenkov-mirovoi, for example, would be juxtaposed with certain nouns (materija, for example) whereas vseobshchee would be more commonly associated with other concepts (razvitija, for example). However, this didn't always hold. Equally it was felt that occasionally mirovoi needed to be translated as "global(ly)," or even in certain circusmtances "world" (so while mirovoi protsess was ren-

9 In certain sections of the text when used together the precise terms in Russian were clarified. 


\section{Giuliano Vivaldi}

dered world process in line with the conventional translation of Hegel's Weltprozess, mirovaya materija was rendered universal matter). There was no easy way to fit the Ilyenkovian mirovoi and vseobshchee $e^{10}$ into the Hegelian Welt and Allgemeinheit, nor to find two distinctive terms in English.

It was indeed not possible to be completely systematic in using a single term in English to transfer single terms in the text, for one convention was pitted against another-in the case of a clear reference to a Hegelian or Spinozan concept, this, then, was to be kept at the expense of translating key vocabulary with a single term (so razum conventionally reason or mind would become Spirit in this specific collocation), just as mirovoi might be rendered variously.

\section{Context}

Ilyenkov's "Cosmology of the Spirit" also needs to be set within its historical context. An early text (although no one has been able to precisely date this piece), one of those texts for the desk drawer as Russians put it (pisat' $v$ iashchik as they put it), it can be read in a number of contexts. Arguably it is primarily a text to be read in the context of Ilyenkov's struggles against the wooden diamat and the mechanistic materialism so influential in Soviet circles in the period of late Stalinism. So Ilyenkov's repeated allusions here are to materialisms not fitting in with the conventional diamats or istmats of conventional Soviet discourse: he links his basic thesis in the piece, that is, that "just as there is no thought without matter, so there is no matter without thought" (Ilyenkov 1991: 417) and using it to contrast, and therefore to separate, the (dialectical) materialism of Spinoza, Engels, and Lenin from the (mechanistic) materialism of Galilei, Newton, Hobbes, and Holbach.

In "Cosmology of the Spirit," Ilyenkov acts just as surgically and brilliantly as he had done when co-authoring with Valentin Korovikov their theses on the subject matter of philosophy in the early 1950s and which brought down on them the censure, opprobrium, and sanctions of the Soviet philosophical establishment of late Stalinism. ${ }^{11}$ In "Cosmology," thought stands out as the Highest Creation. Demonstrating a Hegelian position (even if in sublated form) as opposed to a Kantian strand in philosophy, Ilyenkov's world where the highest reality is still conceivable to

10 Ilyenkov wrote a number of texts on the concept of the vseobshchee, only one of which, however, has been translated into English (Ilyenkov 1975: 26-51).

11 A recent volume, Strasti po tezisam: O predmete filosofii 1954-1955 [Passions on the theses: On the subject of philosophy (1954-1955)] (2016) has attempted to reconstruct both the original theses of Ilyenkov and Korovikov as well as publishing material pertaining to meetings and letters leading to the censoring these two young philosophers, along with further material contextualising the significance of the theses in their historical moment in Soviet thought. 


\section{A Commentary on Evald Ilyenkov's Cosmology of the Spirit}

thought flows into his cosmist vision later in the text of his "pathos of truth [...] of the true consciousness of its objective role in the universal system" before which the hitherto "pathetic pathos" (Ilyenkov 1991: 436) fades (a pathos built on non-dialectical notions such as the essence of God, Providence, or World Spirit). In the description of this pathos reflecting the cosmic and creative (though nonetheless ultimately tragic) role of thought and of humanity, Ilyenkov also went far beyond the orthodox and ultimately barren pathos of "scientific atheism" to comprise a vision of the consciousness of "the cosmic scale of its role in the universe, of its own universal and historical mission" (Ilyenkov 1991: 436); the role of the thinking being as highest creation acquires new features in Ilyenkov due to its significance as a cosmic link in universal interaction. ${ }^{12} \mathrm{~A}$ universal interaction that appears in the form of a big circle (krugovorot) rather than linearly, for as Ilyenkov argues, "the circular character of infinity is the only one which corresponds to the dialectical view" (Ilyenkov 1991: 419). ${ }^{13}$ Based on Pobisk's discovery, however, it was Ilyenkov who fitted in the thinking brain as the fundamental link between the "beginning" and "end" of this big circle, and sought to show how this process could take place concretely through what Aleksei Tsvetkov impressively called Ilyenkov's "Marxist apocalypse" (Tsvetkov 2013). It is in this notion of the big circle and thought as an indispensable link in this chain of true infinity where physics and lyrics, philosophy and science fiction, as well as cosmism and Spinoza most creatively overlap.

That Ilyenkov could forge such a text illuminates a highly subterranean aspect of Soviet intellectual life. Behind the woodenness of discourse (the so-called langue du bois or xyloglossia) of official Soviet discourse emerged figures living in the interstices of the system, who produced a body of work (not just theoretical but also practical) that live on as landmarks of the intellectual history of the twentieth century. ${ }^{14}$ Indeed,

12 It is interesting to note that Ilyenkov's interest in religion is still as yet an under-researched subject. The existence of a play written by Ilyenkov on Christ for the world-renowned Taganka Theatre led by Yuri Liubomov has come to light (a play that sadly wasn't staged)-another one of Ilyenkov's still unpublished works that demonstrates Ilyenkov's versatility as a thinker and not just a philosopher in the narrow sense of the term whose work was reflected in many different literary forms and genres.

13 Mareev points out that this was a conception that Ilyenkov took from Pobisk Kuznetsov's thinking thanks to research by Prigozhin but which very much fits in with the line of thinking that ran from Spinoza to Engels (2015: 159)

14 One practical consequence that should be mentioned of Ilyenkov's philosophy (and, in particular, his activity approach) was his participation in the "Zagorsk experiment" of Aleksandr Meshcheryakov. Meshcheryakov embarked on an educational programme for blind-deaf pupils based based on a theory close to the activty theory of Vygotsky and Ilyenkov. With the help of Ilyenkov at this boarding school, four students of the school were prepared for admission to the Faculty of Psychology of Moscow University, an unheard of achievement anywhere in the world prior to this. 


\section{Giuliano Vivaldi}

Ilyenkov was one of these central figures of this subterranean constellation of thought. Tsvetkov goes so far as to allude to Dostoyevsky's praise of Gogol's story conventionally translated as "the Overcoat," stating that it was from Ilyenkov's frontline greatcoat (or overcoat) that a whole generation of intellectuals (shestidesyatniki) would emerge. A generation including those who remained "inside the system" as well as a generation of dissidents and emigres. It is arguably the liminal, polyvalent quality of Ilyenkov's "Cosmology" signaling the versatility of Ilyenkov's thought which indicated a way out of the strait jacket that Stalinism had held Soviet philosophy in. The nature of the text itself called for a translation attentive to the many different levels of thought, genres and styles present and it is hoped that the necessarily slippery nature of this translation responds to this most fertile of texts in a way that brings out its qualities. After all "Cosmology," arguably, represents one of the most subterranean texts of this subterranean current of Soviet thought.

\section{Bibliography}

Bakhurst, David (1999). Consciousness and Revolution in Soviet Philosophy: from the Bolsheviks to Evald Ilyenkov. Cambridge: Cambridge University Press.

Bakhurst, David (2013). "Soviet Philosophy and Then Some: David Bakhurst Interviewed by Richard Marshall.” 3AM Magazine.http://www.3ammagazine.com/3am/ soviet-philosophy-education-and-thinking-about-reasons/

Barashenkov, V. (1988). “Sud'by Vselennoi: O filosofskoi gipoteze Ėval'da Vasil'evicha Il'enkova" [Judgements of the universe: On the philosophical hypotheses of Evald Vasilevich Ilyenkov]. Nauka i religiia [Science and religion] 10: 5-7.

Engels, Friedrich (1987). “Dialectics of Nature.” In Marx \& Engels Collected Works, Vol. 25, 313-590. London: Lawrence and Wishart.

Hoberman, James (1998). The Red Atlantis: Communist Culture in the Absence of Communism. Philadelphia: Temple University Press.

Ilyenkov, E. V. (1975). “The Universal.” In Philosophical Investigations in the USSR, ed. Frederick J. Adelmann, 26-51. Chestnut Hill, MA: Boston College.

Ilyenkov, E.V. (1991). “Kosmologiya Dukha” [Cosmology of the Spirit]. In Filosofiia $i$ kul'tura [Philosophy and culture], 415-37. Moscow: Politizdat.

Ilyenkov, E.V. (2008). Dialectical Logic. Trans. H. Campbell Creighton. Delhi: Aakar Books.

Ilyenkov, E. V. and Korovikov, V. (2016). Strasti po tezizam: O predmete filosofii 19541955 [Passions on the theses: On the subject of philosophy (1954-1955)]. Moscow: Kanon+.

Kline, George L. (2009). “Shpet as translator of Hegel's Phänomenologie des Geistes.” In Gustav Shpet's Contribution to Philosophy and Cultural Theory, ed. G. Tikhanov, 140-156. West Lafayette, IN: Purdue University Press.

Levant, Alex, and Vesa Oittinen (eds.) (2014). Dialectics of the Ideal: Evald Ilyenkov and Creative Soviet Marxism. Leiden: Brill. 


\section{A Commentary on Evald Ilyenkov's Cosmology of the Spirit}

Maidansky, Andrey. (2014a). "Reality of the Ideal.” In Dialectics of the Ideal: Evald Ilyenkov and Creative Soviet Marxism, ed. Alex Levant and Vesa Oittinen, 125-43. Brill: Leiden.

Maidansky, Andrey. (2014b). “The Dialectical Logic of Evald Ilyenkov and Western European Marxism.” In Russian Thought in Europe: Reception, Polemics, Developments, ed. Theresa Obolevitch, Józef Bremer, Tomasz Homa, 537-49. Krakow: Akademia "Ignatianum” Wydawnictwo WAM.

Mareev, Sergei (2015). E. V. Ilyenkov: Zhit’ filosofiei. Moscow: Akademicheskii Proekt/ Triksta.

Nosov, Nikolay (2007). Prestupnye Filosofy [Criminal philosophers]. Moscow: Olma Press.

Sakata, Siochi (1971). “Theoretical Physics and Dialectics of Nature” [1947]. Supplement. Progress of Theoretical Physics 50. https://www.marxists.org/subject/japan/ sakata/ch01.htm.

Sevastyanov, V. I. (1988). "Filosof Kosmicheskogo Veka” [Philosopher of the cosmic age]. Nauka i Religiia [Science and religion] 9: 19.

Tsvetkov, Aleksei (2013) “O Poslednem Sovetskom Marksiste” [On the last Soviet Marxist]. Prime Magazine. http://primerussia.ru/article_materials/291. 